Vol. 2 | No. 3 | 2021 | Hal. 216-220

\title{
EDUKASI PENTINGNYA PEMBUKUAN BAGI PARA PELAKU USAHA MIKRO KECIL MENENGAH (UMKM)
}

\author{
Eny Zuhrotin Nasyi'ah*, Ellyn Agna Safitri \\ Fakultas Ekonomi dan Bisnis, Universitas Islam Malang \\ *korespondensi email: eny_zu@unisma.ac.id
}

\begin{abstract}
ABSTRAK
Desa Gili Ketapang merupakan salah satu pulau yang berada di Kabupaten Probolinggo. Dalam program KSM-Tematik (Kandidat Sarjana Mengabdi), yang kami pilih adalah 1 mitra usaha olahan makanan. Setelah melakukan survey terhadap mitra UMKM, tim pengabdian masyarakat menemukan beberapa permasalahan, di antaranya: rendahnya tingkat penegetahuan mitra usaha terhadap tata cara pembukuan yang benar dan sesuai dengan prinsip akuntansi, teknik pemasaran secara online, dan kemasana produk yang menarik. Oleh karena itu, program pengabdian masyarakat ini bertujuan untuk melakukan pendampingan UMKM kepada mitra. Metode pelaksanaan dalam pengabdian masyarakat skema KSM (Kandidat Sarjana Mengabdi) ini, antara lain: 1) Sosialisasi dan edukasi tentang dasar-dasar pembukuan, menghitung harga pokok produksi sebelum menentukan harga jual dan cara menghitung laba yang tepat dan 4) pendampingan tentang teknik packing product modern dan pemasaran dengan media digital marketing. Kami menyimpulkan bahwa UMKM selama ini tidak melakukan pembukan, oleh karenanya kedepannya UMKM harus melakukan agar terbiasa dan mempunyai laporan keuangan.
\end{abstract}

Kata Kunci: pembukuan; edukasi; UMKM; desa gili ketapang

\section{PENDAHULUAN}

Keterpurukan perekonomian Indonesia akibat krisis moneter, menjadikan usaha mikro kecil dan menengah sebagai sektor andalan yang paling diminati oleh berbagai kalangan. Sektor UMKM telah terbukti tangguh ketika terjadi krisis ekonomi pada saat ini, hanya sektor UMKM yang bertahan dari kolapsnya ekonomi di masa pandemi Covid-19 sementara sektor yang lebih besar justru tumbang karena krisis. Dengan adanya UMKM maka pengangguran akibat angkatan kerja yang tidak terserap dalam dunia kerja menjadi berkurang. Sektor UMKM juga telah dipromosikan dan dijadikan sebagai agenda utama pembangunan ekonomi Indonesia. Pentingnya peranan UMKM dalam pembangunan di Indonesia saat ini menjadikan pemerintah menaruh perhatian yang cukup besar terhadap berkembangnya sektor UMKM agar menjadi lebih baik dan tertata.

Masyarakat yang ada di pulau Gili Ketapang tidak sedikit yang berprofesi sebagai pengusaha khususnya pelaku usaha UMKM seperti pelaku makanan olahan. Terdapat pelaku usaha UMKM yang telah lama melakukan kegiatan usaha namun usahanya belum dapat berkembang dengan baik. Berdasarkan survey di lapangan menunjukkan bahwa tingginya kegiatan bisnis yang dilakukan oleh pelaku usaha belum disertai dengan pemahaman faktorfaktor pendukung dalam melakukan kegiatan bisnis seperti pembukuan sederhana sehingga 
pelaku usaha hanya fokus pada profit semata tanpa memperhatikan faktor-faktor pendukung usaha.

Salah satu masalah yang dihadapi oleh pelaku UMKM antara lain adalah masalah pembukuan, mereka kurang memiliki kemampuan menerapkan akuntansi. Solusinya adalah sangat penting untuk dilakukan pendampingan dan pelatihan agar dapat mengelola keuangan usahanya secara efektif (Ilsan et al., 2020; Puspitaningtyas, 2017). Menurut Lestari \& Rustiana (2019) pengetahuan pelaku UMKM tentang informasi akuntansi masih perlu dikembangkan sehingga perlu dilakukan upaya untuk meningkatkan pengetahuan pelaku UMKM dalam hal akuntansi, serta upaya perbaikannya agar mereka dapat memanfaatkan informasi akuntansi dalam meningkatkan kualitas pengambilan berbagai keputusan yang dibuatnya. Sesedikit apapun transaksi yang terjadi, sesederhana apapun metode akuntansi yang dipakai, penerapan akuntansi akan memberikan manfaat yang besar bagi kelangsungan suatu usaha (Ediraras, 2010; Rizal et al., 2019).

Menurut Satit et al. (2012) harga merupakan salah satu elemen bauran pemasaran yang paling mempengaruhi keputusan pembelian pelanggan, pelanggan akan lebih bertahan membeli produk kita jika kita menawarkan produk dengan harga yang menarik dan kompetitif atau dengan memberikan diskon khusus. Salah satu unsur yang mempengaruhi volume penjualan adalah kebijakan penetapan harga, harga adalah pengaruh yang paling besar dalam keputusan membeli oleh pelanggan (Zhafira et al., 2013).

Berdasarkan kajian manfaat pemahaman akuntansi dalam pengelolaan keuangan bagi UMKM maka pelaku UMKM perlu diberikan penyuluhan dan pelatihan pembukuan sederhana. Di desa Gili Ketapang Kecamatan Sumberasih, Kabupaten Probolinggo mayoritas pelaku usaha belum memahami bagaimana menyusun pembukuan sederhana yang fungsi utamanya adalah mengetahui setiap transaksi usaha baik penerimaan maupun pengeluaran. Pengabdian kepada masyarakat dilaksanakan dengan fokus pada pelaku usaha UMKM di desa Gili Ketapang dengan tujuan agar pelaku usaha UMKM mendapatkan pemahaman pembukuan. Pemahaman yang diperoleh tersebut dapat diterapkan dalam kegiatan usaha dan dapat memperbaiki kualitas usaha yang dikelola. Dengan pelatihan pembukuan sederhana ini diharapkan mereka dapat menentukan biaya-biaya bahan baku dan operasional untuk menentuka harga jual dan selanjutnya dapat menghitung berapa laba yang mereka peroleh.

\section{METODE}

Pelaksanaan Kandidat Sarjana Mengabdi (KSM) Tematik Universitas Islam Malang berbasis domisili yang dilaksanakan pada tanggal 02 Agustus - 02 September 2021, yang beretempat di desa Gili Ketapang, Kecamatan Sumberasih, Kabupaten Probolinggo Jawa Timur. Adapun sasaran yang menjadi objek dan subjek kegiatana pentingnya pembukuan adalah para pelaku umkm kerupuk ikan jenggelek desa Gili Ketapang.

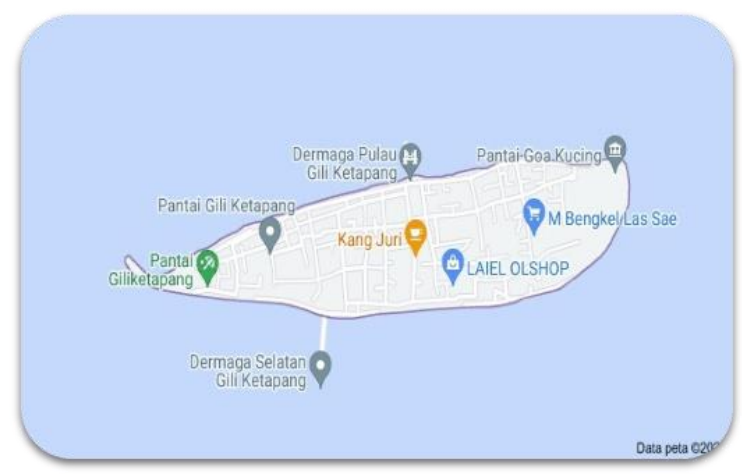

Gambar 1. Peta lokasi Desa Gili Ketapang Kecamatan Sumberasih Kabupaten Probolinggo 
Dalam pelaksanaan program kerja sosialisasi dan edukasi pentingnya pembukuan disini kita menggunakan alat bantu buku tulis, alat tulis dan alat hitung. Karena pelaku UMKM kurang memahami alat bantu aplikasi dan kurangnya alat elektronik yang mereka miliki, oleh sebab itu kita para tim hanya bisa mengajarkan pembukuan berbasis manual kepada pelaku UMKM.

\section{Tahapan Kegiatan dan Metode Pembelajaran}

Tahap persiapan, yang dilakukan untuk mempersiapkan berbagai hal sebelum melakukan kegiatan yang meliputi menjalin komunikasi dengan mitra, melakukan studi pendahuluan (survei lapangan), mengidentifikasi setiap permasalahan pada mitra dan melakukan penyusunan rencana pemecahan masalah.

Tahap pelaksanaan, yang meliputi pendampingan dan pembinaan untuk mitra yang dipilih dan memberikan solusi untuk setiap permasalahan pada setiap mitra yang sudah ditelaah, permasalahan yang ditindak lanjuti meliputi permasalahan dalam bidang pembukuan, teknik pemasaran digital, tata cara pembayaran menggunakan uang elektronik dan, teknik packing product modern. Permasalahan ini didasari oleh pengetahuan pengelolaan UMKM melakukan pembukuan.

Tahap evaluasi dan penutup, dimana permasalahan-permasalahan yang ditemukan dari peserta pelatihan menjadi bahan diskusi dan kajian bersama, kemudian ditawarkan solusi alternatifnya sebagai solusi akhir dan diberikan kesimpulan dan penutupan dari hasil kegiatan secara jelas dan menyeluruh.

\section{HASIL DAN PEMBAHASAN}

Selama kami melaksanakan program sosialisasi dan edukasi pentingnya pembukuan di Desa Gili Ketapang, kami memiliki output yang akan kita capai, di antaranya (1) Pelaku UMKM memahami dasar-dasar pembukuan untuk pelaku UMKM; (2) Pelaku UMKM dapat mengetahui biaya produksi sehingga dapat menentukan harga jual; (3) Pelaku UMKM dapat menghitung keuntungan dari usahanya sehingga lebih mudah mengatur strategi dalam pengembangan usaha.

Kegiatan yang bertemakan Edukasi Pentingnya Pembukuan yang selama ini dilakukan memiliki tahap sebagai berikut:

\section{Mengunjungi Rumah Pelaku UMKM}

Mahasiswa Kandidat Sarjana Mengabdi (KSM) melakukan kunjungan guna mencari permasalahan dan hambatan yang ada pada pelaku UMKM. Berdasarkan pengamatan kami bahwa salah satu penyebab sulitnya usaha kerupuk ikan jenggelek sulit berkembang dikarenakan para pelaku usaha tidak mengetahui dimana posisi persaingan mereka di pasar. Terdapat empat hal yang perlu dipahami oleh pelaku usaha untuk memenangkan pasar yaitu produk, harga, distribusi dan komunikasi. Maka disini kami memberikan pemahaman manfaat pembukuan khususnya dalam menentukan harga jual.

Menurut Bapak Sukadji salah satu tokoh pelaku usaha kerupuk ikan jenggelek menganggap bahwa penyelenggaraan pembukuan dianggap ribet dan bertele-tele. Akibatnya mereka tidak memiliki informasi keuangan yang akurat, keuangan tercampur sehingga tidak bisa memisahkan harta usaha dan harta pribadi. 


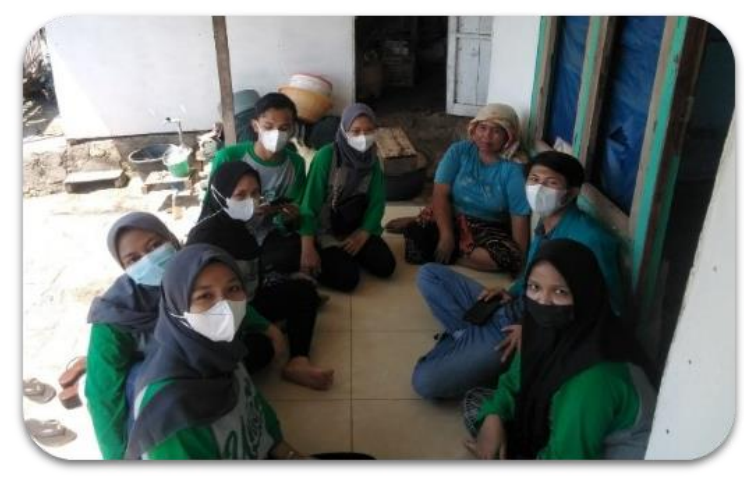

Gambar 2. Diskusi Awal Kendala dan Permasalahan

\section{Evaluasi Pembuatan Pembukuan Sederhana Kepada Pelaku UMKM}

Mahasiswa Kandidat Sarjana Mengabdi (KSM) mengajarkan Bapak Sukadji bagaimana cara mencatat pemasukan dan pengeluaran menggunakan buku kas dengan 3 kolom yaitu debit, kredit, dan saldo. Dengan adanya sosialisasi dan edukasi mengenai pembukuan sederhana diharapkan pelaku UMKM lebih mudah memahami laba dan rugi setiap bulan, selain itu pelaku UMKM juga bisa mengetahui kemajuan usaha yang dimilikinya. Jadi tidak selalu hasil penjualan setiap hari hanya untuk dibelanjakan kembali dan pelaku UMKM sudah tahu berapa hasil laba bersih yang diperolehnya.

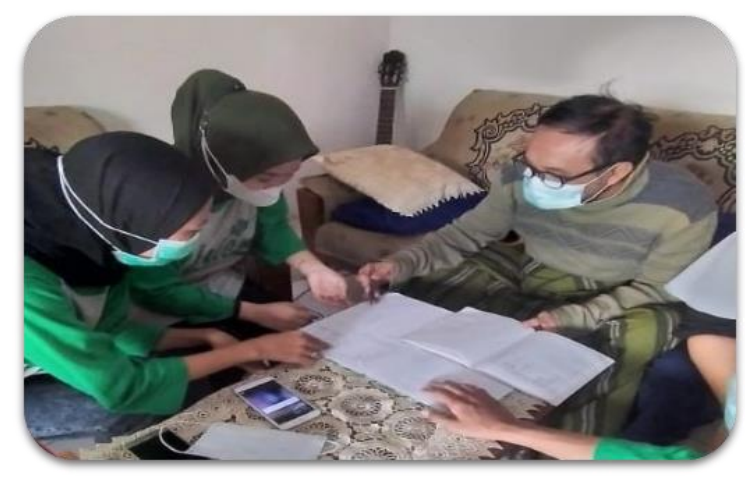

Gambar 3. Pelatihan Pembukuan

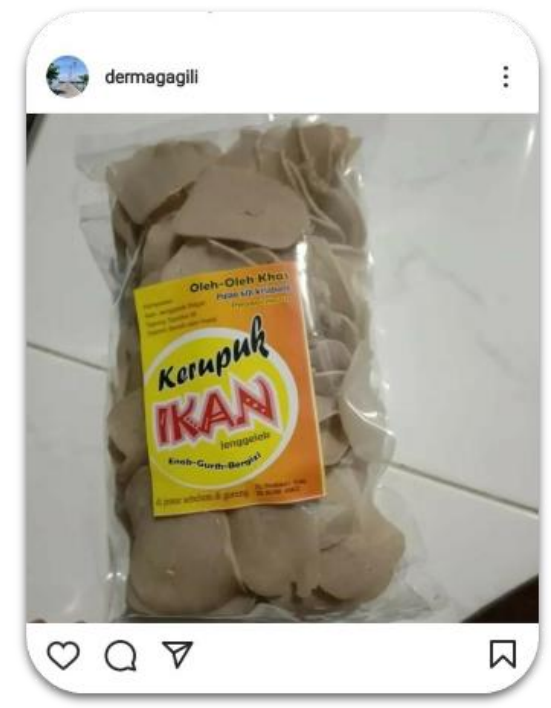

Gambar 4. Produk Kerupuk Ikan 


\section{Mengedukasi Mempromosikan Produk Melalui Media Sosial}

Sebagai tahap penyempurnaan agar UMKM dapat memperluas pangsa pasarnya maka pada tahap akhir selain edukasi tata cara pembukuan, kami mahasiswa Kandidat Sarjana Mengabdi (KSM) juga mengedukasi cara mempromosikan produk melalui media sosial karena selama ini ditemui kendala dari media promosi produk ini yaitu pelaku UMKM hanya bisa menggunakan media sosial, tidak bisa menggunakan market place. Dengan keterbatasan media promosi maka pelaku UMKM hanya bisa mengirimkan di daerah Jawa Timur saja.

\section{KESIMPULAN}

Pelaksanaan program pelatihan ini, mulai dari tahap persiapan sampai pelaksananya dapat kami simpulkan temuan-temuan sebagai berikut: (1) UMKM tidak mengetahui cara membuat dan membaca laporan keuangan, selama ini tidak ada pemisahan dan penghitungan biaya produksi dan untuk konsumsi keluarga, sehingga mereka tidak dapat mendapatkan nilai laba yang sesungguhnya; (2) UMKM perlu disiplin dan membiasakan melakukan pembukuan untuk usahanya, agar terbiasa dan mempunyai laporan keuangan sebagai alat pengukur kinerja dan juga untuk pengajuan modal kepada perbankan, investor atau lembaga keuangan lainnya..

\section{UCAPAN TERIMA KASIH}

Terimakasih Kepada Bapak Sukadji Sebagai Pelaku Usaha UMKM Kerupuk Ikan Jenggelek

\section{DAFTAR RUJUKAN}

Ediraras, D. (2010). Akuntansi dan Kinerja UKM. Jurnal Ilmiah Ekonomi Bisnis, 15(2), 152158. https://ejournal.gunadarma.ac.id/index.php/ekbis/article/view/331

Ilsan, M., Salim, M., \& Husain, T. K. (2020). Pelatihan teknik menyusun laporan keuangan untuk umkm agribisnis. Jurnal Inovasi Hasil Pengabdian Masyarakat (JIPEMAS), 3(2), 102-110. https://doi.org/10.33474/jipemas.v3i2.5993

Lestari, N. A., \& Rustiana, S. H. (2019). Pengaruh Persepsi Owner dan Pengetahuan Akuntansi dalam Penggunaan Sistem Informasi Akuntansi terhadap Kinerja Usaha Mikro, Kecil, dan Menengah di Pamulang. BASKARA: Journal of Business and Entrepreneurship, 1(2), 67-80. https://doi.org/10.24853/baskara.1.2.67-80

Puspitaningtyas, Z. (2017). Pembudayaan Pengelolaan Keuangan Berbasis Akuntansi bagi Pelaku Usaha Kecil Menengah. Jurnal Akuntansi, 21(3), 361-372. https://doi.org/10.24912/ja.v21i3.242

Rizal, M., Mustapita, A. F., \& Kartika Sari, A. F. (2019). Pelatihan Untuk Pengajuan Pembiayaan Mudharabah Perbankan Syariah Sebagai Peningkatan Kinerja UMKM. Jurnal Inovasi Hasil Pengabdian Masyarakat (JIPEMAS), 3(1), 15-22. https://doi.org/10.33474/jipemas.v3i1.2569

Satit, R. P., Huam, H. T., Tat, A. T., \& Rasli, A. (2012). The Relationship Between Marketing Mix And Customer Decision-Making Over Travel Agents: An Empirical Study. International Journal of Academic Research in Business and Social Sciences, 2(6), 522.

Zhafira, N. H., Andreti, J., Akmal, S. S., \& Kumar, S. (2013). The Analysis of Product, Price, Place, Promotion and Service Quality on Customers' Buying Decision of Convenience Store: A Survey of Young Adult in Bekasi, West Java, Indonesia. International Journal of Advances in Management and Economics, 2(6), 72-78. https://www.managementjournal.info/index.php/IJAME/article/view/332 